\title{
Mass Isolation of Pollen Protoplasts in Brassica Crops and Wild Allies
}

\author{
Harufumi Minami*, Yoshihito Takahata** and Daisuke Hogetsu* \\ * Tokyo Metropolitan Isotope Research Center, 2-11-1 Fukazawa, Setagaya, Tokyo 158, Japan \\ ** Faculty of Agriculture, Iwate University, Ueda, Morioka 020, Japan
}

(Received August 16, 1994)

(Accepted February 4, 1995)

\begin{abstract}
A number of pollen protoplasts were isolated enzymatically from mature pollen(tricellular pollen) of Brassica napus and B. campestris. All the protoplasts were viable and had one vegetative and two sperm nuclei. Osmoticum in enzyme solution had much effect on the protoplast isolation. The high efficiency of protoplast isolation(86-88\%) was achieved with $1.0 \mathrm{M}$ osmoticum (0.8 M mannitol+0.2 M sucrose). Protoplast yield decreased greatly with reducing osmoticum. Pollen protoplasts were released from mature pollen of 13 strains of 10 species classified in tribe Brassiceae with a frequency of $15-64 \%$, but not from those of Matthiola incana in tribe Matthioleae.
\end{abstract}

\section{Introduction}

Pollen is a natural vector of genes. Pollen containing foreign genes of a transgenic plant can be used to transfer foreign genes into another cross compatible plant by artifitial pollination. Direct DNA transfer into pollen has been shown in a few papers ${ }^{1-3)}$. Pollen protoplasts can provide a better means to directly introduce foreign genes in plants. Furthermore pollen protoplasts can be used the production of gametosomatic hybrids through cell fusion ${ }^{4,5)}$. A number of pollen protoplasts also contribute to the effective isolation of sperm cells ${ }^{6)}$ and the study of fertilization in angiosprems ${ }^{7-11)}$.

Pollen protoplasts have been enzymatically isolated from various stages of pollen development in several species. Tetrad pollen protoplasts have been obtained in Datura metel ${ }^{12)}$, Atropa belladonna, Nicotiana tabacum, Triticum aestivum ${ }^{13)}$, Ulmus americana ${ }^{14)}$ and Digitalis obscura ${ }^{15)}$. The high yield of protoplasts from uninucleate pollen has been obtained in Asparagus officinalis ${ }^{16)}$. The high yield isolation of protoplasts from mature pollen has been reported in Iris tectorium, Zephyranthes grandiflora, Hemerocallis fulva ${ }^{17)}$ and Lilium longiflorum ${ }^{18)}$. However, protoplasts have not been isolated from mature pollen of tricellular species.

The genus Brassica includes tricellular species. The genus contains many economically important oilseed, vegetable, condiment and ornamental crops. Much work on protoplast isolation from somatic cells and cell fusion has been carried out on Brassica and wild allies ${ }^{19-21)}$. However, the isolation of protoplasts from pollen have not been reported for these plants. In this paper, we report the isolation of high yield of mature pollen protoplasts from Brassica (tricellular species) and allied species. 


\section{Materials and Methods}

\section{Experiment 1. Determination of optimum osmoticum for isolation of pollen protoplasts} Plant materials

B. napus cv. Lisandra and B. campestris cv. Jhonankomatsuna were used in this study. The seeds of the former were obtained from Dr. Y. Ohkawa, Chugoku National Agriculture Experiment Station and those of the latter were from seed stocks of Tokyo Metropolitan Isotope Research Center. Both of the plants were grown in the field and flowered during late May to early June in Tokyo.

\section{Isolation of pollen protoplasts}

Anthers were collected from the flower buds one day before flowering. Pollen was released by gently squeezing the anthers in Lichter's mineral salts ${ }^{22)}$ (NLNM) supplemented with $13 \%$ sucrose and filtered through $62 \mu \mathrm{m}$ pore size nylon sieve. The pollen was incubated in an enzyme solution at the density of $1.0 \times 10^{4} \mathrm{~m} l^{-1}$ for $2 \mathrm{~h}$ at $28^{\circ} \mathrm{C}$ in the dark. The enzyme solution contained $0.1 \%(\mathrm{w} /$ v) Macerozyme R-10 (Yakult Pharmaceutical Co. Ltd. Japan) and 0. 1\% (w/v) Cellulase Onozuka RS (Yakult Pharmaceutical Co. Ltd. Japan), NLNM as mineral salts and mannitol and sucrose as osmoticum of $1.0 \mathrm{M}, 0.7 \mathrm{M}$ and $0.5 \mathrm{M}$ described in Table 1. $1.0 \mathrm{M}$ osmoticum consisted of $0.8 \mathrm{M}$ mannitol and 0.2 M sucrose because of the difficulty in making the enzyme solution containing 1. 0 $\mathrm{M}$ mannitol due to the solubility limit at the room temperature. The yield of protoplasts under $0.8 \mathrm{M}$ mannitol $+0.2 \mathrm{M}$ sucrose was as same as under $1.0 \mathrm{M}$ mannitol. The enzyme solutions were adjusted to $\mathrm{pH}$ 5.8. The isolated pollen protoplasts were washed twice with NLNM medium containing $0.8 \mathrm{M}$ mannitol by centrifugation at $1,200 \mathrm{rpm}$ for $3 \mathrm{~min}$. Protoplast yield was determined using a haemocytometer.

The degree of cell wall digestion and the protoplast viability were confirmed with $0.1 \%$ calcofluor white and fluorescein diacetate ${ }^{23)}$, respectively. Vegetative and sperm nuclei were observed by staining with $0.1 \mu \mathrm{g} \mathrm{m} l^{-1} \mathrm{DAPI}\left(4^{\prime} 6\right.$-diamidino-2-phenylindole) in $0.5 \mathrm{M}$ mannitol.

\section{Experiment 2. Effect of genotypes in isolation of pollen protoplasts}

Nine strains of six crop species (B. napus, B. campestris, B. oleracea, Raphanus sativus, Eruca sativa and Matthiola incana) and five wild species (B. deflexa, Diplotaxis erucoides, Erucastrum varium, Hirshefeldia incana and Moricandia arvensis) were used. Of these, R. sativus cv. Sayatoridaikon and M. incana was obtained from Mr. Y. Kuginuki, National Research Institute of Vegetables, Ornamental Plant and Tea and Mr. T. Ohya, respectively. They were grown in the greenhouse and flowered during mid January to February in Morioka. The protocols of isolation of pollen protoplasts were carried out as described in Experiment 1, except that $0.8 \mathrm{M}$ mannitol +0.2

Table 1. Effect of osmoticum on pollen protoplast isolation in Brassica napus and Brassica campestris.

\begin{tabular}{clcc}
\hline \multicolumn{1}{c}{ Osmoticum } & \multicolumn{1}{c}{ Species } & $\begin{array}{l}\text { Isolated protoplasts } \\
\text { Means } \pm \mathrm{SE}^{* 1}(\%)\end{array}$ & $\begin{array}{l}\text { Viability of } \\
\text { protoplasts }(\%)\end{array}$ \\
\hline 0.8 M mannitol & B. napus & $88 \pm 5$ & 100 \\
+0.2 M sucrose & B. campestris & $86 \pm 3$ & 100 \\
0.7 M mannitol & B. napus & $19 \pm 6$ & 100 \\
& B. campestris & $17 \pm 9$ & 100 \\
$0.5 \mathrm{M}$ mannitol & B. napus & a few & \\
& B. campestris & a few & \\
\hline
\end{tabular}

${ }^{* 1}$ Values are the means of at least three replications. Each replication is carried out in five buds randomly chosen from three to five plants. 
M sucrose was used as osmoticum in the enzyme solution.

\section{Results}

The yield of isolated protoplasts from mature pollen differed according to the strength of osmoticum in the enzyme solution for B. napus and B. campestris (Table 1). The highest frequency of protoplasts was obtained with $0.8 \mathrm{M}$ mannitol+0.2 M sucrose, reaching about $90 \%$ of the treated pollen. The cell wall of pollen was partly digested within $0.5 \mathrm{~h}$ incubation in the enzyme solution. Part of pollen protoplast, which showed spherical and was not stained with calcofluor white, appeared from the germinal apertures(Fig. 1-a). After $2 \mathrm{~h}$ incubation, almost all protoplasts were released from the pollen(Fig. 1-b), and were ascertained to be viable with FDA staining (Fig. 1-c). Staining with DAPI revealed that all of the protoplasts had one vegetative nucleus and two sperm nuclei(Fig. 1-d). Similar results in the yield of protoplasts and microscopic observation were obtained in two strains (rapid cycling and var. italica) of $B$. olevacea (data not shown).

On the other hand, the percentage of protoplast isolation decreased with the reduction of
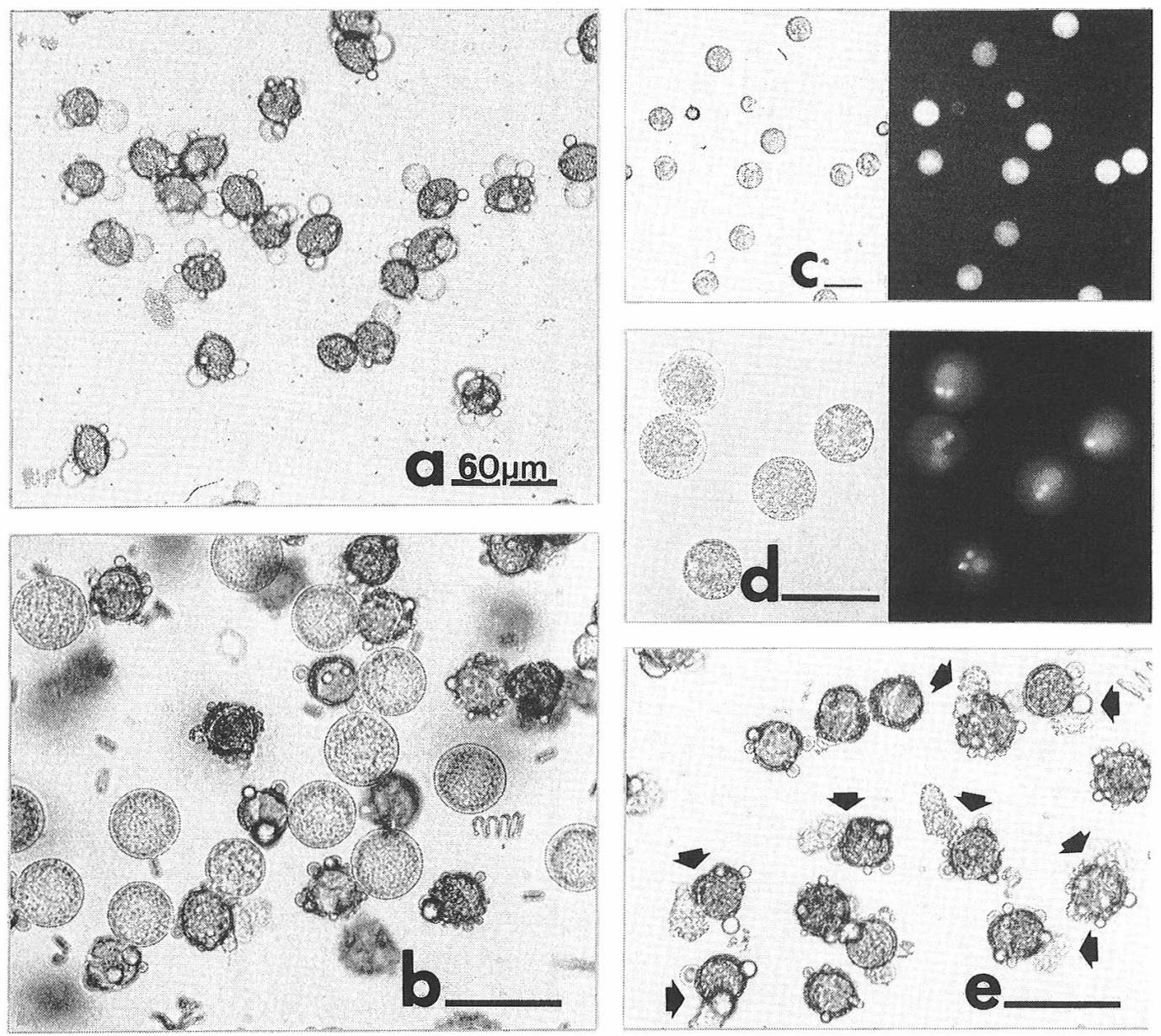

Fig. 1 Protoplast isolation from mature pollen of Brassica napus.

(a) Start of release of pollen protoplasts from germinal apertures after $0.5 \mathrm{~h}$ incubation in the enzyme solution containing $0.8 \mathrm{M}$ mannitol $+0.2 \mathrm{M}$ sucrose. (b) Pollen protoplasts isolated after $2 \mathrm{~h}$ incubation.(c) Pollen protoplasts stained with fluorescein diacetate. (d) One vegetative nucleus and two sperm nuclei stained with DAPI in a pollen protoplast. (e) Pollen burst after $2 \mathrm{~h}$ incubation in the enzyme solution containing $0.7 \mathrm{M}$ mannitol. Arrows show burst pollen. 
Table 2. Yields of pollen protoplasts in Brassica crops and wild allies.

\begin{tabular}{|c|c|c|}
\hline \multirow{2}{*}{ Species } & \multicolumn{2}{|c|}{ Isolated protoplast $(\%)$} \\
\hline & Mean $\pm \mathrm{SE}^{* 1}$ & Range \\
\hline \multicolumn{3}{|l|}{ Tribe Brassiceae } \\
\hline \multicolumn{3}{|l|}{ Subtribe Brassicinae } \\
\hline \multicolumn{3}{|l|}{ Brassica napus } \\
\hline cv. Topas & $58 \pm 21$ & $38-89$ \\
\hline cv. Tower & $33 \pm 12$ & $25-55$ \\
\hline \multicolumn{3}{|c|}{ B. campestris ssp. pekinensis } \\
\hline cv. Ho Mei & $25 \pm 0$ & 25 \\
\hline \multicolumn{3}{|l|}{ B. oleracea var. italica } \\
\hline strain B 31-18 & $15 \pm 12$ & $0-30$ \\
\hline B. deflexa & $28 \pm 10$ & $21-42$ \\
\hline Diplotaxis erucoides & $51 \pm 24$ & $19-77$ \\
\hline Eruca sativa & $29 \pm 0$ & 29 \\
\hline Erucastrum varium & $64 \pm 18$ & $39-77$ \\
\hline Hirschfeldia incana & $15 \pm 21$ & $0-45$ \\
\hline \multicolumn{3}{|l|}{ Subtribe Raphaninae } \\
\hline \multicolumn{3}{|l|}{ Raphanus sativus } \\
\hline cv. Chugokuaodaikon & $30 \pm 11$ & $23-45$ \\
\hline cv. Sushirazushougoin & $38 \pm 0$ & 38 \\
\hline cv. Sayatoridaikon & $36 \pm 15$ & $18-54$ \\
\hline \multicolumn{3}{|l|}{ Subtribe Moricandiae } \\
\hline Moricandia arvensis & $45 \pm 9$ & $39-58$ \\
\hline \multicolumn{3}{|l|}{ Tribe Matthioleae } \\
\hline Matthiola incana & 0 & \\
\hline
\end{tabular}

Protoplasts were isolated in the enzyme solution containing $0.8 \mathrm{M}$ mannitol+ $0.2 \mathrm{M}$ sucrose.

${ }^{* 1}$ Values are the means of at least three replications.

osmoticum in the enzyme solution. When $0.7 \mathrm{M}$ mannitol was used as osmoticum protoplasts were isolated from $20 \%$. When $0.5 \mathrm{M}$ mannitol was used only a few protoplasts were isolated(Table 1). Though pollen did not burst and were stained with FDA in $0.7 \mathrm{M}$ and $0.5 \mathrm{M}$ mannitol solution without enzymes, most of the pollen burst in the enzyme solution containing $0.7 \mathrm{M}$ or $0.5 \mathrm{M}$ mannitol(Fig. 1-e). The frequency of pollen burst in the enzyme solution containing $0.5 \mathrm{M}$ mannitol was higher than that in $0.7 \mathrm{M}$ mannitol. Protoplasts could be isolated only rarely using any osmoticum from late uninucleate to early binucleate microspore.

When the enzyme solution containing $0.8 \mathrm{M}$ mannitol+0.2 M sucrose was used in other species or genotypes, protoplasts were isolated from mature pollen of all species except one (Table 2) and were confirmed to be viable with FDA staining. However, species or genotypes had a significant effect on the protoplast yield. The highest frequency of protoplast isolation(more than 50\%) was obtained in B. napus cv. Topas, D. erucoides and E. varium. $45 \%$ of pollen released the protoplasts in $M$. arvensis. Three genotypes of $R$. sativus showed the similar frequency of protoplast isolation $(30-38 \%)$. The frequency (33\%) of pollen protoplasts in B. napus cv. Tower was lower than that in cv. Topas. Fewer protoplasts from $29 \%$ to $15 \%$ were released in E. sativa, B. deflexa, B. campestris cv. Ho Mei, B. oleracea var. italica B31-18 and H. incana. On the other hand, hardly any protoplasts were isolated from pollen of $M$. incana. 


\section{Discussion}

The present results indicated that the osmoticum in the enzyme solution had a significant influence on the isolation of protoplasts from mature pollen of Brassica napus and campestris. A similar result has been reported for asparagus ${ }^{16)}$. In all previous reports ${ }^{16-18,24)}$, pollen protoplasts in angiosperm plants have been isolated under $0.3-0.7 \mathrm{M}$ osmoticum. Their range of osmoticum was not efficient for the protoplast isolation from Brassica pollen. The protoplast was effectively isolated with $1.0 \mathrm{M}$ osmoticum. Our results indicate that the optimum osmoticum for isolation of pollen protoplasts in Brassica is higher than that in the other plants.

The protoplast yield in Exp. 2 was lower than that in Exp. 1. For example, protoplasts were isolated from about $90 \%$ mature pollen of B. napus and campestris in Exp. 1, although the frequency of isolated protoplasts reduced to $25-58 \%$ in Exp. 2. This may be due to the difference of genotypes as reported in Allium $^{24)}$ or physiological conditions of donor plants grown in different environments.

Large variation in protoplast yield was observed among species or genotypes. This is consistent with the results of Allium $^{24)}$. Of the species used in this study, those which were classified into tribe Brassiceae and could cross Brassica crops $^{25)}$ released protoplasts from their mature pollen under the same osmoticum as $B$. napus and campestris. In contrast, $M$. incana in tribe Matthioleae, which is distantly related to and could not cross Brassica crops, could not release any protoplasts. These results indicate that the enzyme solution optimized for $B$. napus and campestris in this study can be applied to related species, but not to distantly related ones.

The isolated protoplast of $B$. napus cv. Lisandra form a region stained with aniline blue on their surface but hardly divided at present.

\section{Acknowledgments}

We thank Dr. Y. Ohkawa for providing B. napus cv. Lisandra seeds, Mr. Y. Kuginuki R. saivus cv. Sayatoridaikon seeds, Mr. T. Ohya for M. incana plants and Mrs. R. Suzuki(Iwate university)for her helpful assistance.

\section{References}

1) Twell, D., T. M. Klein, M. E. Fromm, S. McCormick, 1989. Plant Physiol., 91: 1270-1274.

2) Süssmuth, J., K. Dressler, D. Hess, 1991. Bot. Acta, 104: 72-76.

3) Morikawa, H., M. Nishihara, M. Seki, K. Irifune, 1994. J. Plant Res., 107: 117-123.

4) Pirrie, J. B., J. B. Power, 1986. Theor. Appl. Genet., 72: 48-52.

5) Lee, C. H., J. B. Power, 1988. Plant Cell Rep., 7: 17-18.

6) Tanaka, I., 1988. Protoplasma, 142: 68-73.

7) Kranz, E., J. Bautor, H. Lörz, 1991. Sex Plant Reprod, 4: 12-16.

8) Faure, J. E., C. Digonnet, C. Dumas, 1994. Science, 263: 1598-1600.

9) Roeckel, P., A. Chaboud, E. Matthys-Rochon, S. Russell, C. Dumas, 1990. In “Microspores" (eds. by Blackmore, S. B., R. B. Knox), p. 281-307, Academic Press, London.

10) Russell, S. D., 1991. In “Annu. Rev. Plant Physiol. Plant Mol. Biol.” vol. 42 (ed. by Briggs, W. R.), p. 189204, Annual Reviews, Palo Alt.

11) Theunis, C. H., E. S. Pierson, M. Cresti, 1991. Sex Plant Reprod, 4: 145-154.

12) Rajasekhar, E. W., 1973. Nature, 246: 223-224.

13) Bajaj, Y. P. S., M. R. Davey, B. W. Grout, 1975. In "Gametic Competition in Plants and Animals" (ed. by Mulcahy, D. L.), p. 7-18, North-Holland Publishing Company, Amsterdam.

14) Redengaugh, M. K., R. D. Westfall, D. F. Karnosky, 1980. Can. J. For Res., 10: 284-289. 
15) Arnalte, E., P. Perez-Bermudez, M. J. Cormejo, J. Segura, 1991. J. Plant Physiol., 138: 622-624.

16) Kunitake, H., J. Godo, M. Mii, 1993. Japan. J. Breed., 43: 231-238.

17) Zhou, C., 1989. Plant Sci., 59: 101-108.

18) Tanaka, I., C. Kitazume, M. Ito, 1987. Plant Sci., 50: 205-211.

19) Gleba, Y., F. Hoffmann, 1980. Planta, 149: 112-117.

20) Glimelius, K., 1984. Physiol. Plant., 61: 38-44.

21) Klimaszewska, K., W. Keller, 1987. Plant Cell Tiss. Org. Cult., 8: 225-233.

22) Lichiter, R. L., 1981. Z. Pflanzenphysiol., 103: 229-238.

23) Heslop-Harrison, J., Y. Heslop-Harrison, 1970. Stain Technol., 45: 115-120.

24) Fellner, M., P. Havránek, 1992. Plant Cell Tiss. Org. Cult., 29: 275-279.

25) Warwick, S. I., L. D. Black, 1993. Guide to the wild germplasm of Brassica and allied crops. Part III Interspecific and intergeneric hybridization in the tribe Brassiceae(Cruciferae). Research Branch Technical Bulletin 1993-16E, Agr. Canada, Ottawa.

\title{
《和文要約》
}

\author{
アブラナ属作物および野生種成熟花粉からのプロトプラスト大量単離 \\ 南 晴文*・高畑義人**・宝月大輔* \\ * 東京都立アイソトープ総合研究所 \\ ** 岩手大学農学部
}

大量の花粉プロトプラストが, Brassica napus 抢よび B. campestris の成熟花粉から酵素処理 $(0.1 \%$ マセ ロザイム R-10，0.1\% セルラーゼ・オノズカ RS)をすることによって単離された，単離された花粉プロトプ ラストのすべてに，活性があることが認められた。また，それらプロトプラストには 1 個の栄養核および 2 個の精核があることも確認された。プロトプラストの単離収量は, $1.0 \mathrm{M}(0.8 \mathrm{M}$ マニトール+0.2 M シュ クロース)の浸透圧下で最も高く，処理花粉の 86 ～ $88 \%$ に相当した，その収量は，浸透圧の低下に伴い急 激に減少し，0.7 M (0.7 M マニトール)の浸透圧下では，17〜19\% となった。また，Brassiceae 連に属す るアブラナ属近縁種の 7 種では，15～64\% と種間差が認められたものの成熟花粉からのプロトプラストが 単離された。一方, Matthioleae 連に属する Matthiola incana では, 花粉プロトプラストは全く単離され なかった。 